\title{
SEASONAL CHANGE OF AEROBIC PERFORMANCE OF YOUNG SOCCER PLAYERS
}

\section{CAMBIO ESTACIONAL DEL RENDIMIENTO AERÓBICO DE JUGADORES DE FÚTBOL JÓVENES}

\author{
Gürkan Diker ${ }^{1}$, Raif Zileli ${ }^{2}$, Hüseyin Özkamçı ${ }^{3}$, Sadi Ön ${ }^{4}$ \\ gdiker@cumhuriyet.edu.tr; raif.zileli@bilecik.edu.tr; huseyin.ozkamci@deu.edu.tr; \\ sadi.on@ahievran.edu.tr \\ ${ }^{1}$ Sivas Cumhuriyet University, Sivas, Turkey \\ 2 Bilecik Şeyh Edebali University, Bilecik, Turkey \\ ${ }^{3}$ Dokuz Eylül University, İzmir, Turkey \\ ${ }^{4}$ Ahi Evran University, Kırşehir, Turkey
}

Original submission: 2020-11-11 Resubmitted: 2021-04-14 Accepted: 2021-05-12

Published: 2021-05-25

\section{Doi: https://doi.org/10.15517/pensarmov.v19i1.44517}

\begin{abstract}
Longitudinal studies evaluating the seasonal change of aerobic capacity in young soccer players of different age categories are limited. The aim of this study was to investigate the seasonal changes in the aerobic level of the youth academy players of a professional soccer team. This research study was carried out with a total of 51 soccer players in the U14, U15, $\mathrm{U} 16, \mathrm{U} 17$, and $\mathrm{U} 18$ categories of an elite soccer team. Aerobic capacities of the athletes were measured by Yo-YOIRT 1 Test. In the analyses, the normal distribution evaluations of the data were made with the Shapiro-Wilk test and the variance homogeneities were tested with the Levene's Test. One Way ANOVA test was used to analyze all the parametric data. All statistical evaluations were performed with the help of the SPSS 21 package program. According to the Yo-YOIRT 1 test, increases or decreases were determined in the pre-season, mid-season and end-of-season evaluations. As a result, in the present study conducted to examine the seasonal changes of the young elite soccer players in the U14, U15, U16, U17, and U18 categories, Yo-YOIRT 1 values in all categories increased significantly at the end of the season when compared to the pre-season and the mid-season. $U 14$ and $U 16$ age groups gained increasing acceleration starting from the pre-season. However, in the U15, U17, U18 age groups, the case is that acceleration decreases in the middle of the season and increases at the end of the season. It is thought that differences can be observed in the responses to the training loads during maturation. It can be suggested that the increase at the end of the season
\end{abstract}


compared to the pre-season in all groups may be due to the fact that the adaptation of the athletes to the training programs are affected by the developmental characteristics regarding the age categories over time.

Keywords: aerobic change, yo-yoirt1, soccer

\section{Resumen}

Los estudios longitudinales que evalúan el cambio estacional de la capacidad aeróbica de los jugadores de fútbol jóvenes de diferentes categorías de edad son limitados. El objetivo de este estudio fue investigar los cambios estacionales del nivel aeróbico de los jugadores de la academia juvenil de un equipo de fútbol profesional. Esta investigación se realizó a un total de 51 futbolistas de las categorías U14, U15, U16, U17 y U18 de un equipo de fútbol de élite. Las capacidades aeróbicas de los atletas se midieron mediante la prueba Yo-YoIRT 1. En los análisis, las evaluaciones de distribución normal de los datos se realizaron con la prueba de Shapiro-Wilk y las homogeneidades de varianza se probaron con la prueba de Levene. Se utilizó la prueba una vía ANOVA para analizar todos los datos paramétricos; todas las evaluaciones estadísticas se realizaron con la ayuda del programa SPSS 21 . De acuerdo con la prueba Yo-YoIRT 1, se determinaron aumentos y/o disminuciones en las evaluaciones de pretemporada, mitad de temporada y final de temporada. Como resultado, en el presente estudio realizado para examinar los cambios estacionales de los jóvenes futbolistas de élite en las categorías U14, U15, U16, U17 y U18, los valores de Yo-YoIRT 1 en todas las categorías aumentaron significativamente al final de la temporada, en comparación con la pretemporada y la temporada media. Los grupos de edad U14 y U16 lograron una aceleración creciente a partir de la pretemporada. Sin embargo, en los grupos de edad U15, U17, U18, el caso es que la aceleración disminuye en la mitad de la temporada y aumenta al final de la temporada. Se cree que se pueden observar diferencias en las respuestas a las cargas de entrenamiento durante el crecimiento y la maduración. Se puede sugerir que el incremento al final de la temporada respecto a la pretemporada, en todos los grupos, puede deberse a que la adaptación de los deportistas a los programas de entrenamiento se ve afectada por las características del desarrollo en cuanto a las categorías de edad a lo largo del tiempo.

Palabras clave: cambio aeróbico, yo-yo IRT 1, fútbol. 


\section{INTRODUCTION}

Considering the duration of the soccer game, aerobic metabolism is dominant. This reveals that the aerobic endurance feature is an important condition for success in soccer. However, it is not possible to talk about aerobic metabolism as the key to success in soccer. Due to the multifactorial nature of soccer, besides the development of aerobic methods for success, many features such as anaerobic structures, technical and tactical dimensions, psychological state, among others, must be at a high level. The association of recovery between high-intensity activities in the game with aerobic metabolism makes the aerobic endurance feature more important (Vanttinen, Blomqvist, Nyman, \& Hakkinen, 2011; Hammami et al., 2013; Sagelv et al., 2019).

Physical characteristics of soccer players are known to improve with biological age and training age. It was emphasized that the soccer game is a sport that requires the fitness levels of soccer players to be constant at a high level, but the foundations of physical performance should be formed during their youth (Dragijsky, Maly, Zahalka, Kunzmann, \& Hank, 2017). In terms of talent development, soccer players between 15 and 18 years old are in a critical development period (Sæther \& Aspvik, 2014). It is known that the increases in aerobic performance with the training performed has positive improvements in combating the stress faced by soccer players during the match (Helgerud, Engen, Wisløff, \& Hoff 2001; Impellizzeri et al., 2006). The capacity of soccer players to gain and maintain good physiological performance throughout the season is very important (Reilly \& Williams, 2003). It is important to determine what effects this may have on pre-season and seasonal change levels (Caldwell \& Peters, 2009).

Yo-YOIRT 1 is a valid field test widely used in soccer. The widespread use of YO-YOIRT 1 is due to its simplicity, low cost, and the ability to test several players at the same time. (Fanchini et al., 2014). Yo-YoIRT 1 gives results similar to laboratory tests in the evaluation of $\mathrm{VO}_{2 \max }$ (Sylejmani et al., 2019). Studies have shown that it is associated with the high-intensity activities during a match and it informs about competition levels throughout the season (Bangsbo, laia, \& Krustru, 2008; Mohr \& Krustrup, 2014). Yo-YOIRT 1 has significant correlations with the total distance $(r=0.62)$ and the high-intensity distance $(r=0.73)$ of sports athletes in the underage teams (Roe \& Malone, 2016).

Although there are studies investigating the seasonal changes of soccer players, there is no study investigating the aerobic levels of the players of different age groups of a professional soccer team with the same soccer culture. Knowing the changes in aerobic capacity of youth academy players in pre-season, mid-season and end-of-season will provide important information for optimal performance and enable critical periods to be determined. This study predicts that aerobic capacity increase as the soccer players' ages increase. Within the frame of this hypothesis, we assumed that there would be differences in seasonal variation 
depending on the age of the teams in different categories. If looked from, it is anticipated that this research would contribute significantly to the identification of critical stages in the development of soccer players trained in youth academies. In addition, being aware of the weaknesses of the players during their youth and training for them are considered to be important in reaching the optimal performance level by eliminating these weaknesses until adulthood. Based on the above information, the purpose of this study is to investigate the seasonal changes in the aerobic levels of the youth academy players in the $U 14, U 15, U 16$, $\mathrm{U} 17$, and $\mathrm{U} 18$ categories of a professional team.

\section{MATERIAL AND METHODS}

Participants

This research study was carried out with the participation of 51 soccer players in the categories of U14, U15, U16, U17, and U18 of a professional soccer team (for U14 n: 12, the average age is $13.06 \pm 0.32$ years, height is $167.08 \pm 7.66 \mathrm{~cm}$, body weight is $54.40 \pm 7.35 \mathrm{~kg}$; for U15 $\mathrm{n}: 9$, the average age is $14.50 \pm 0.30$ years, height is $174.66 \pm 6.42 \mathrm{~cm}$, body weight is $65.55 \pm 5.81 \mathrm{~kg}$; for $\mathrm{U} 16 \mathrm{n}: 12$, the average age is $15.60 \pm 0.34$ years, height is $174.83 \pm 6.32 \mathrm{~cm}$, body weight is $66.08 \pm 7.08 \mathrm{~kg}$; for $\mathrm{U} 17 \mathrm{n}$ : 8 , the average age is $16.30 \pm 0.57$ years, height is $175.25 \pm 0.08 \mathrm{~cm}$, body weight is $68.30 \pm 4.86 \mathrm{~kg}$; for $U 18 \mathrm{n}$ : 10 , the average age is $17.50 \pm 0.55$ years, height is $176.50 \pm 5.12 \mathrm{~cm}$, body weight is $69.30 \pm 4.83 \mathrm{~kg}$ ) (Table 1). Ethics committee report was received from Bilecik Şeyh Edebali University Ethics Committee before the study started $(2019 / 3 / 5)$. After all the volunteers were verbally informed prior to the study, the written informed consent was obtained from their parents.

\section{Measures}

The heights of the athletes participating in the test were measured with a Holtain brand (England) stadiometer with an accuracy of $\pm 1 \mathrm{~mm}$. Body weights of the volunteers participating in the test were measured with a TANITA MC780 (JAPAN) scale, which measures with an accuracy of $\pm 0.1 \mathrm{~kg}$. Test Signals were implemented with the help of PRO SPORT TMR ESC 1000 TEST TIMER developed by Tümer Prosport Limited Company, and speed signals were given according to the speeds set from the tempo timer.

\section{Anthropometric Measurements}

The heights of the subjects were measured in an anatomical posture, bare feet, toe heels united, and while the subject was holding the breath. The head was measured in the frontal plane after the overhead table was positioned at the vertex point, and the values were recorded in centimeters. Body weights were taken in $\mathrm{kg}$ when the subjects were in bare feet and an anatomical posture, with only shorts on. 


\section{Aerobic Fitness}

Maximal aerobic capacities of the soccer players were measured in meters with Yo$\mathrm{YO}_{\mathrm{IRT1}}$. This is a test in which speed increases regularly. The test consists of a track with 20 meters of shuttle runs; there is a $5+5$-meter recovery section where athletes actively rest at the end of each round. If the athlete fails to reach the finish line twice in time, the test is considered to be completed and the distance covered by the athlete is evaluated as the YoYoIRT1 performance. At the first level of this test, there are a total of 4 shuttle runs and the speed is $10-13 \mathrm{~km} / \mathrm{h}$; At the second level, there are 7 shuttle runs and speeds are $13.5-14$ $\mathrm{km} / \mathrm{h}$; and the next levels consist of 8 shuttle runs and a $0.5 \mathrm{~km} / \mathrm{h}$ speed increase, which continued until the athlete was exhausted or two successive mistakes were made. Besides, the following formula was used in order to calculate $\mathrm{VO}_{2 \max }$ :

Yo-YOIRT ${ }_{1} \mathrm{VO}_{2 \max }\left(\mathrm{ml} / \mathrm{kg}^{-1} / \mathrm{min}^{-1}\right)$ :

Running Distance x 0.0084+36.4 (Bangsbo et al., 2008).

\section{Design and Procedures}

All tests were conducted at the end of the first preparation period (pre), at the end of the first competition period (mid), and at the end of the second competition period (end) at the same time of the day. Warm-up was performed for 10 minutes before all tests. During the tests, verbal suggestions were made so that the athletes could reach their maximum effort levels.

\section{Statistical Analysis}

After the descriptive statistics of the volunteers were calculated, the data was tested using the Shapiro-Wilk test to determine whether it showed a normal distribution and the variance homogeneities were evaluated with the Levene test separately for each category. As the data were all parametric, the analysis was carried out using One Way ANOVA test. Then, a post hoc test-Bonferroni- was used. Cohen's d effect sizes were also calculated and the outputs were described as follows: $<0.20$ (trivial), 0.20-0.59 (small), 0.6-1.19 (moderate), 1.21.99 (large); $\geq 2.0$ (very large) (Hopkins, Marshall, Batterham, \& Hanin, 2009). Futhermore, the development ratio (\%) was calculated. Statistical data was tested using the SPSS 21 Package program. The significance level was set at $p<0.005$. 


\section{RESULTS}

Table 1.

Physical Properties of the Participants Playing in U14, U15, U16, U17 and U18 Categories

\begin{tabular}{lccccc}
\hline & U14 & U15 & U16 & U17 & U18 \\
& $\overline{\mathbf{x} \pm \text { sd }}$ & $\overline{\mathbf{x}} \pm \mathbf{~ s d}$ & $\overline{\mathbf{x}} \pm \mathbf{~ s d}$ & $\overline{\mathbf{x}} \pm \mathbf{~ s d}$ & $\overline{\mathbf{x}} \pm \mathbf{~ s d}$ \\
\hline Age (years) & $13.06 \pm 0.32$ & $14.50 \pm 0.30$ & $15.60 \pm 0.34$ & $16.30 \pm 0.57$ & $17.50 \pm 0.55$ \\
\hline Height (cm) & $167.08 \pm 7.66$ & $174.66 \pm 6.42$ & $174.83 \pm 6.32$ & $175.25 \pm 0.08$ & $176.50 \pm 5.12$ \\
\hline Body Weight (kg) & $54.40 \pm 7.35$ & $65.55 \pm 5.81$ & $66.08 \pm 7.08$ & $68.30 \pm 4.86$ & $69.30 \pm 4.83$ \\
\hline
\end{tabular}

Note. $\bar{x}$ : mean sd: standard deviation. Source: the author 
Table 2.

YO-YOIRT 1(m) Values and Development Rates of the Participants Pre-season, Mid-season and End-of-season

\begin{tabular}{|c|c|c|c|c|c|c|c|c|}
\hline & $\begin{array}{c}\text { Pre } \\
\overline{\mathbf{x}} \pm \mathbf{s d} \\
(\mathrm{m})\end{array}$ & $\begin{array}{c}\text { Mid } \\
\overline{\mathbf{x}} \pm \mathbf{s d} \\
(\mathrm{m})\end{array}$ & $\begin{array}{l}\text { End } \\
\overline{\mathbf{x}} \pm \mathbf{s d} \\
(\mathrm{m})\end{array}$ & $f$ & p & $\begin{array}{c}\text { pre-mid } \\
(\%) / \text { Cohen } d / p\end{array}$ & $\begin{array}{c}\text { mid-end } \\
(\%) / \text { Cohen } d / p\end{array}$ & $\begin{array}{c}\text { pre-end } \\
(\%) / C o h e n d / p\end{array}$ \\
\hline U14 & $1520.00 \pm 311.13$ & $1583.33 \pm 326.06$ & $1800.00 \pm 293.57$ & 4.39 & $0.001^{*}$ & $7.47 / 0.41 / 0.238$ & $13.68 / 0.69 / 0.002^{*}$ & $22.17 / 1.33 / 0.002^{*}$ \\
\hline U15 & $1473.33 \pm 184.36$ & $1315.55 \pm 395.19$ & $1968.88 \pm 300.52$ & 537.39 & $0.001^{*}$ & $-13.45 / 0.57 / 0.256$ & $49.66 / 1.86 / 0.024^{*}$ & $29.53 / 1.46 / 0.042^{*}$ \\
\hline U16 & $1626.67 \pm 404.10$ & $1870.00 \pm 272.43$ & $2360.00 \pm 276.08$ & 773.82 & $0.001^{*}$ & $14.95 / 0.71 / 0.189$ & $26.20 / 1.79 / 0.001^{*}$ & $47.54 / 2.12 / 0.001^{*}$ \\
\hline U17 & $2255.00 \pm 178.80$ & $2102.50 \pm 242.24$ & $2660.00 \pm 249.34$ & 2873.99 & $0.001^{*}$ & $-6.76 / 0.72 / 0.688$ & $26.52 / 2.27 / 0.015^{*}$ & 17.96/1.87/0.005* \\
\hline U18 & $2024.00 \pm 282.34$ & $1904.00 \pm 444.30$ & $2272.00 \pm 330.28$ & 459.66 & $0.001^{*}$ & $-5.93 / 0.32 / 0.878$ & $19.33 / 0.94 / 0.045^{*}$ & $12.25 / 0.81 / 0.0028 *$ \\
\hline
\end{tabular}

Note. $\bar{x}$ : arithmetic mean, sd: standard deviation, pre: pre-season measurement (meter), mid: mid-season measurement (meter), end: end-season measurement (meter), \% development rate (\%), effect size: Cohen $d,{ }^{*} p<0.005$. Source: the author 
Yo-YoIRT1 results of all groups at different times are given in Table 2. Yo-YoIRT1 development percentage in the U14 age category increased by $7.47 \%$ in the mid-season compared to the beginning of the season, by $13.68 \%$ at the end of the season compared to the middle of the season, and by $22.17 \%$ at the end of the season compared to the beginning of the season. In the U15 age category, it decreased by $13.47 \%$ in the mid-season compared to the beginning of the season, increased by $49.66 \%$ at the end of the season compared to the mid-season and increased by $29.53 \%$ at the end of the season compared to the beginning of the season. In the U16 age category, it increased by $14.95 \%$ in the mid-season compared to the beginning of the season, increased by $26.20 \%$ at the end of the season compared to the mid- season and increased by $47.54 \%$ at the end of the season compared to the beginning of the season. In the U17 age category, it decreased by $6.76 \%$ in the mid-season compared to the beginning of the season, increased by $26.52 \%$ at the end of the season compared to the mid-season, and increased by $17.96 \%$ at the end of the season compared to the beginning of the season. In the U18 age category, it was observed to decrease by $5.93 \%$ in the midseason compared to the beginning of the season, increase by $19.33 \%$ at the end of the season compared to the mid-season, and increase by $12.25 \%$ at the end of the season compared to the beginning of the season. 
Table 3.

Estimated $\mathrm{VO}_{2 \max }$ Values of the Participants Pre-season, Mid-season and End-of-season

\begin{tabular}{|c|c|c|c|c|c|c|c|c|}
\hline & $\begin{array}{c}\text { Pre } \\
\overline{\mathbf{X}} \pm \mathbf{s d} \\
\left(\mathrm{ml} / \mathrm{kg}^{-1} / \mathrm{min}^{-1}\right)\end{array}$ & $\begin{array}{c}\text { Mid } \\
\overline{\mathbf{X}} \pm \mathbf{s d} \\
\left(\mathrm{ml} / \mathrm{kg}^{-1} / \mathrm{min}^{-1}\right)\end{array}$ & $\begin{array}{c}\text { End } \\
\overline{\mathbf{x}} \pm \mathbf{s d} \\
\left(\mathrm{ml} / \mathrm{kg}^{-1} / \mathrm{min}^{-1}\right)\end{array}$ & $f$ & $p$ & $\begin{array}{c}\text { pre-mid } \\
\mathbf{p}\end{array}$ & $\begin{array}{c}\text { mid-end } \\
\mathbf{p}\end{array}$ & $\begin{array}{c}\text { pre-eno } \\
\text { p }\end{array}$ \\
\hline U14 & $48.77 \pm 1.55$ & $49.71 \pm 2.74$ & $51.52 \pm 2.45$ & 6659.491 & $0.001^{*}$ & 0.387 & $0.001^{*}$ & $0.001^{*}$ \\
\hline U15 & $49.15 \pm 2.61$ & $47.43 \pm 3.31$ & $52.93 \pm 2.54$ & 7478.072 & $0.001^{*}$ & 0.261 & $0.024^{*}$ & $0.042^{*}$ \\
\hline U16 & $50.07 \pm 3.39$ & $52.13 \pm 2.30$ & $56.21 \pm 2.31$ & 8114.228 & $0.001^{*}$ & 0.192 & $0.001^{*}$ & $0.001^{*}$ \\
\hline U17 & $55.34 \pm 1.52$ & $54.07 \pm 2.04$ & $58.74 \pm 2.09$ & 23534.002 & $0.001^{*}$ & 0.711 & $0.008^{*}$ & $0.016^{*}$ \\
\hline U18 & $53.43 \pm 2.38$ & $52.39 \pm 3.73$ & $55.49 \pm 2.77$ & 4392.713 & $0.001^{*}$ & 0.828 & $0.044^{*}$ & $0.029^{*}$ \\
\hline
\end{tabular}

Note. $\bar{x}$ : arithmetic mean, sd: standard deviation, pre: pre-season measurement $\left(\mathrm{ml}^{\mathrm{k}} \mathrm{kg}^{-1} / \mathrm{min}^{-1}\right)$, mid: mid-season measurement $\left(\mathrm{ml}^{\prime} / \mathrm{kg}^{-1} / \mathrm{min}^{-1}\right)$, end: end-season measurement $\left(\mathrm{ml}^{1} \mathrm{~kg}^{-1} / \mathrm{min}^{-1}\right){ }^{*} \mathrm{p}<0.005$. Source: the author 
$\mathrm{VO}_{2 \max }$ results of all groups at different times are given in Table 3. Change in $\mathrm{VO}_{2 \max }$ in all age categories for mid-seasons, the beginning of the season and the end of the season was observed.

In the U14 age category, it increased from $48.77 \mathrm{ml} / \mathrm{kg}^{-1} / \mathrm{min}^{-1}$ to $49.71 \mathrm{ml} / \mathrm{kg}^{-1} / \mathrm{min}^{-1}$ in the mid-season compared to the beginning of the season. It increased from $49.71 \mathrm{ml} / \mathrm{kg}^{-1} / \mathrm{min}^{-}$ ${ }^{1}$ to $51.52 \mathrm{ml} / \mathrm{kg}^{-1} / \mathrm{min}^{-1}$ at the beginning of the season compared to the end of the season. It increased from $48.77 \mathrm{ml} / \mathrm{kg}^{-1} / \mathrm{min}^{-1}$ to $51.52 \mathrm{ml} / \mathrm{kg}^{-1} / \mathrm{min}^{-1}$ at the end of the season compared to the beginning of the season. In the $U 15$ age category, it decreased from $49.15 \mathrm{ml} / \mathrm{kg}^{-1} / \mathrm{min}^{-1}$ to $47.43 \mathrm{ml} / \mathrm{kg}^{-1} / \mathrm{min}^{-1}$ in the mid-season compared to the beginning of the season, increased from $47.43 \mathrm{ml} / \mathrm{kg}^{-1} / \mathrm{min}^{-1}$ to $52.93 \mathrm{ml} / \mathrm{kg}^{-1} / \mathrm{min}^{-1}$ at the end of the season compared to the mid-season and increased from $49.15 \mathrm{ml} / \mathrm{kg}^{-1} / \mathrm{min}^{-1}$ to $52.93 \mathrm{ml} / \mathrm{kg}^{-1} / \mathrm{min}^{-1}$ at the end of the season compared to the beginning of the season. In the U16 age category, it increased from 50.07 $\mathrm{ml} / \mathrm{kg}^{-1} / \mathrm{min}^{-1}$ to $52.13 \mathrm{ml} / \mathrm{kg}^{-1} / \mathrm{min}^{-1}$ in the mid-season compared to the beginning of the season, increased from $52.13 \mathrm{ml} / \mathrm{kg}^{-1} / \mathrm{min}^{-1}$ to $56.21 \mathrm{ml} / \mathrm{kg}^{-1} / \mathrm{min}^{-1}$ at the end of the season compared to the mid-season and increased from $50.07 \mathrm{ml} / \mathrm{kg}^{-1} / \mathrm{min}^{-1}$ to $56.21 \mathrm{ml} / \mathrm{kg}^{-1} / \mathrm{min}^{-1}$ at the end of the season compared to the beginning of the season. In the $\mathrm{U} 17$ age category, it decreased from $55.34 \mathrm{ml} / \mathrm{kg}^{-1} / \mathrm{min}^{-1}$ to $54.07 \mathrm{ml} / \mathrm{kg}^{-1} / \mathrm{min}^{-1}$ in the mid-season compared to the beginning of the season, increased from $54.07 \mathrm{ml} / \mathrm{kg}^{-1} / \mathrm{min}^{-1}$ to $58.74 \mathrm{ml} / \mathrm{kg}^{-1} / \mathrm{min}^{-1}$ at the end of the season compared to the mid-season, and increased from $55.34 \mathrm{ml} / \mathrm{kg}^{-1} / \mathrm{min}^{-1}$ to $58.74 \mathrm{ml} / \mathrm{kg}^{-1} / \mathrm{min}^{-1}$ at the end of the season compared to the beginning of the season. In the U18 age category, it decreased from $53.43 \mathrm{ml} / \mathrm{kg}^{-1} / \mathrm{min}^{-1}$ to $52.39 \mathrm{ml} / \mathrm{kg}^{-1} / \mathrm{min}^{-1}$ in the mid-season compared to the beginning of the season, increased from $52.39 \mathrm{ml} / \mathrm{kg}^{-1} / \mathrm{min}^{-1}$ to $55.49 \mathrm{ml} / \mathrm{kg}^{-1} / \mathrm{min}^{-1}$ at the end of the season compared to the mid-season, and increased from $53.43 \mathrm{ml} / \mathrm{kg}^{-1} / \mathrm{min}^{-1}$ to 55.49 $\mathrm{ml} / \mathrm{kg}^{-1} / \mathrm{min}^{-1}$ at the end of the season compared to the beginning of the season. 


\section{DISCUSSION}

The purpose of this study was to investigate the seasonal changes in the aerobic levels of the youth academy players of a professional soccer team in the $U 14, U 15, U 16, U 17$, and U18 categories.

The aerobic system and the anaerobic system are considered to be very important in soccer game. However, during a 90-minute soccer match, the main source of Adenosine Triphospate (ATP) production is regarded as the aerobic system. The maximum aerobic power determined by the maximum oxygen intake can vary depending on the league and the positions in which the soccer players participate (Vanttinen et al., 2011; Teplan et al., 2012).

In the present study, aerobic development increased statistically significantly at the end of the season compared to the mid-season and similarly at the end of the season compared to the beginning of the season in all age categories $(p<0.005)$. At the end of the season, the highest development was in the U16 category (47.54\%), followed by the U15 (29.53\%), U14 (22.17\%), U17 (17.96\%) and U18 (12.25\%) categories. In U15, U17, and U18 categories, a decreasing percentage was observed in mid-season compared to the beginning of the season, but these rates were not statistically significant $(p>0.005)$. All teams reached their highest running distance at the end of the season. While the percentage of development at the end of the season is higher in U16 and the younger age groups, the running distance is higher in U16 and older age groups (Table 2). Besides, $\mathrm{VO}_{2 \max }$ increased at the end of the season compared to the beginning of the season in all age categories (U14 from $48.77 \mathrm{ml} / \mathrm{kg}^{-1} / \mathrm{min}^{-1}$ to 51.52 $\mathrm{ml} / \mathrm{kg}^{-1} / \mathrm{min}^{-1}$, U15 from $49.15 \mathrm{ml} / \mathrm{kg}^{-1} / \mathrm{min}^{-1}$ to $52.93 \mathrm{ml} / \mathrm{kg}^{-1} / \mathrm{min}^{-1}$, U16 from $50.07 \mathrm{ml} / \mathrm{kg}^{-1} / \mathrm{min}^{-1}$ to $56.21 \mathrm{ml} / \mathrm{kg}^{-1} / \mathrm{min}^{-1}$, U17 from $55.34 \mathrm{ml} / \mathrm{kg}^{-1} / \mathrm{min}^{-1}$ to $58.74 \mathrm{ml} / \mathrm{kg}^{-1} / \mathrm{min}^{-1}$, U18 from 53.43 $\mathrm{ml} / \mathrm{kg}^{-1} / \mathrm{min}^{-1}$ to $55.49 \mathrm{ml} / \mathrm{kg}^{-1} / \mathrm{min}^{-1}$ ) (Table 3). Standard deviation in Yo-YoIRT 1 and $\mathrm{VO}_{2 \max }$ parameters of athletes differ in terms of the data obtained at the beginning, in the middle and at the end of the season. This change shows that all of the athletes were affected disparately from the training.

The increase in aerobic capacity is expected to be the usual effect of pre-season training (Jastrzębski, Dargiewicz, et al., 2011). Nevertheless, there are studies revealing that $\mathrm{VO}_{2 \max }$ increases at the end of the preparation period (McMillan et al., 2005; Jastrzębski, Barnat, Konieczna, Rompa, \& Radzimiński, et al., 2011; Charalampos, Zisis, Asterios \& Nikolaos, $\underline{2013}$ ). Other studies asserting that $\mathrm{VO}_{2 \max }$ decreases at the end of the competition period (Mohr, Krustrup, \& Bangsbo et al., 2002; Mohr, Krustrup, \& Bangsbo, 2003, Dragijsky et al., 2017). Besides, evidence shows that $\mathrm{VO}_{2 \max }$ increases during the entire competition period (Edwards, Clark, \& Macfadyen, 2003). When the literature is reviewed, it is possible to come across some contradictory findings.

Dragijsky et al. (2017) reported that in their study carried out with the participation of 28 players from the $\mathrm{U} 13$ category of a professional team in the Czech League, the average Yo- 
YoIRT 1 values of the players gradually increased at a statistically significant level compared to the beginning of the season and decreased at the end of the competition period (t1-beginning of the pre-season training period $625.26 \mathrm{~m}$; t2-start of the competitive period $858.95 \mathrm{~m}$; $\mathrm{t} 3$ middle of the competitive period $953.68 \mathrm{~m}$; t4-end of the competitive period $924.21 \mathrm{~m}$ ).

Multi-stage Fitness Test and Yo-YOIRT 1 Test can be interchangeably used to predict $\mathrm{VO}_{2 \max }$ (Thomas, Dawson, \& Goodman, 2006). Caldwell \& Peters also found the $\mathrm{VO}_{2 \max }$ value $\left(56 \mathrm{ml} / \mathrm{kg}^{-1} / \mathrm{min}^{-1}\right)$ at the beginning of the season lower than other periods of the season using the Multi-stage Fitness Test (Caldwell \& Peters, 2009). Similar to the U14 and U16 age group results in the present study; Silva et al. (2015), in their study with elite young soccer players aged 17 , reported that the running distance increased (35\%) according to the Yo-YOIRT 1 test results obtained at the end of the week 5 of a 7 -week preparation period. In the study where the development of the male soccer players in the U16 category was followed for an 8-week period, Hammami et al. (2013) reported an increase in Yo-YoIRT $1\left(\mathrm{VO}_{2} \max\right.$ from 47.9 to 55.7 $\mathrm{ml} / \mathrm{kg}^{-1} / \mathrm{min}^{-1}$ ) performances of the players. Vanttinen et al. (2011) in their study with the (Yo-

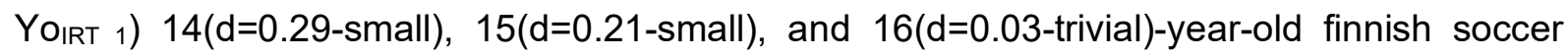
players in the a-year follow-up in response to cardiovascular endurance reported identical findings to the current study.

In soccer-related studies, it was emphasized that the short off-season (8 weeks) was associated with a decrease in aerobic fitness level (Reilly \& Williams, 2003) and an increase in body fat percentage (Hoshikawa et al., 2005). In the studies which showed that the level of aerobic fitness in soccer players increased in the mid-season compared to the pre-season and decreased at the end of the season, the reason for the increase in $\mathrm{VO}_{2 \max }$ in the mid-season compared to the beginning of the season stemmed from the training and competitions, and this situation was associated with the decrease in body fat percentage. They emphasized that the decrease in $V_{2} O_{2 m}$ in the second half of the season might be caused by overload/overtraining and fatigue at the end of the season (Haritonidis, Koutlianos, Koudi, Haritonidou, \& Deligiannis, 2004; Caldwell \& Peters, 2009).

Aerobic performance development in young adolescents is related to the performance in the matches. The development of aerobic performance is affected by the process of biological maturation and weekly training volume (Teixeira et al., 2014). The most important factor that can affect the sportive condition of the player and the whole team in a comprehensive way is the training load (Jastrzębski, Dargiewicz, et al., 2011). Studies show that exposure to training loads among elite young soccer players increased between the ages of 11 and 19 (BaxterJones \& Helms, 1996; Brito et al., 2012; Malina et al., 2000). "Practice makes perfect" is a wellknown expression in most sports, including soccer. However, severe training and match load increase the risk of injury, weariness and burnout (Sæther \& Aspvik, 2014). The pressure to be successful for talented players is felt at earlier ages (Hill, 2013). 
Researchers have suggested that such players, who had a low level of condition at the start of the season, had to work extremely hard to reach the high level they required. They also argue that to start the season in such a short time may be associated with a potentially high catabolic condition, causing mental and physical fatigue later in the season (Kraemer et al., 2004). Pressure to be successful can lead to a potential lack of motivation and burnout (Sæther \& Aspvik, 2014). Hill (2013) stated that one out of four 13-16 years-old players selected for a British professional club experienced burnout at least once in their career (Hill, 2013).

According to the research findings of young soccer players, the period in which growth / development and individual differences are most evident is between 11 and 16 years old. On the other hand, there is limited information about late adolescent soccer players aged 17-19 (Sylejmani et al.,2019).

Furthermore, it should be noted that the training process in young players has an important role in their development and positively affects the development of individual components of their athletic performance (Dragijsky et al., 2017) because systematic young academy soccer education increases physical and physiological development in young soccer players, but maturity status is affected by these processes in different ways (Morris et al., 2018).

In addition to the positive adaptations from training, changes in performance in youth athletes will also reflect the effects of normal growth and maturation, therefore any conclusions regarding the magnitude of performance improvement to specific training must account for changes in maturation. As such this highlights the importance of considering physical testing results in the context of maturation status when evaluating the performance of youth soccer players (Emmonds, Sawczuk, Scantlebury, Till, \& Jones, 2020).

Moreover, to the beneficial improvements of training, changes in the success of young athletes will likely demonstrate the results of natural development and maturation, thus all assumptions on the extent of skill adjustment of individual preparation will account for the changes in maturation. This emphasizes the importance of considering the results of physical testing in the context of maturation status when evaluating the performance of young soccer players (Emmonds et al., 2020).

\section{CONCLUSIONS}

The present study aimed to examine the seasonal changes of the young elite soccer players in the $\mathrm{U} 14, \mathrm{U} 15, \mathrm{U} 16, \mathrm{U} 17$, and $\mathrm{U} 18$ categories. The findings show that the aerobic performance of U14 and U16 age groups increased from the beginning of the season to the end of the season.

When we look at the mean values the aerobic performance of the $\mathrm{U} 15, \mathrm{U} 17, \mathrm{U} 18$ age groups, we can state that there is a decrease in the middle of the season and increase at the 
end of the season. While the increase is statistically significant, the decrease is not statistically significant. However, this decrease is worthy of notice. It is thought that some differences in the responses to the training loads during maturation can be observed (Roe \& Malone, 2016). Significant increase at the end of the season compared to the beginning of the season in all groups may be due to the fact that the adaptation of the athletes to the training programs was positively affected by the development characteristics according to the age categories. For this reason, carefully selected trainings should be performed in all age categories according to the developmental characteristics of the athletes. Furthermore, the development of the athletes should be tested at short intervals.

\section{REFERENCES}

Bangsbo, J., laia, F.M. \& Krustrup, P. (2008). The Yo-Yo intermittent recovery test. Sports Medicine, 38(1), 37-51. doi: https://doi.org/10.2165/00007256-200838010-00004

Baxter-Jones, A.D.G. \& Helms, P.J. (1996). Effects of training at a young age: A review of the training of young athletes (TOYA) study. Pediatric Exercise Science, 8(4), 310-327. doi: https://doi.org/10.1123/PES.8.4.310

Brito, J., Malina, R.M., Seabra, A., Massada, J.L., Soares, J.M., Krustrup, P. \& Rebelo, A. (2012). Injuries in Portuguese youth soccer players during training and match play. Journal of Athletic Training, 47(2), 191-197. doi: https://doi.org/10.4085/1062-6050$\underline{47.2 .191}$

Caldwell, B.P. \& Peters, D.M. (2009). Seasonal variation in physiological fitness of a semiprofessional soccer team. Journal of Strength and Conditioning Research, 23(5), 1370-1377. doi: https://doi.org/10.1519/JSC.0b013e3181a4e82f

Charalampos, P., Zisis, P., Asterios, P. \& Nikolaos, M. (2013). Comparison of two physical conditioning programs in improving aerobic endurance in moderately trained youth amateur soccer players during the preparation period. Journal of Physical Education and Sport, 13(3), 419-424. doi: https://doi.org/10.7752/jpes.2013.03067

Dragijsky, M., Maly, T., Zahalka, F., Kunzmann, E., \& Hank, M. (2017). Seasonal variation of agility, speed and endurance performance in young elite soccer players. Sports, 5(1), 1-8. doi: $\underline{\text { https://doi.org/10.3390/sports5010012 }}$

Edwards, A.M., Clark, N. \& Macfadyen, A. M. (2003). Lactate and ventilatory thresholds reflect the training status of professional soccer players where maximum aerobic power is unchanged. Journal of Sports Science and Medicine, 2(1), 23-29. Retrieved from https://www.ncbi.nlm.nih.gov/pmc/articles/PMC3937571/

Emmonds, S., Sawczuk, T., Scantlebury, S., Till, K. \& Jones, B. (2020). Seasonal changes in the physical performance of elite youth female soccer players. Journal of Strength and 
Conditional Research, 34(9), 2636-2643. doi: https://doi.org/10.1519/JSC.0000000000002943

Fanchini, M., Castagna, C., Coutts, A.J., Schena, F., McCallf, A. \& Impellizzeri FM. (2014). Are the Yo-Yo intermittent recovery test levels 1 and 2 both useful? Reliability, responsiveness and interchangeability in young soccer players. Journal of Sports Sciences, 32(20), 1950-195. doi: https://doi.org/10.1080/02640414.2014.969295

Hammami, M.A., Ben Abderrahmane, A., Nebigh, A., Le Moal, E., Ben Ounis, O., Tabka, Z. \& Zouhal, H. (2013). Effects of a soccer season on anthropometric characteristics and physical fitness in elite young soccer players. Journal of Sports Sciences, 31(6), 58996. doi: https://doi.org/10.1080/02640414.2012.746721

Haritonidis, K., Koutlianos, N., Koudi, E., Haritonidou, M. \& Deligiannis, A. (2004). Seasonal variation of aerobic capacity in elite soccer, basketball and volleyball players. Journal of Human Movement Studies, 46(4), 289-302. Retrieved from https://www.researchgate.net/publication/292003543 Seasonal variation of aerobic capacity in elite soccer basketball and volleyball players

Helgerud, J., Engen, L.C., Wisløff, U., \& Hoff, J. (2001). Aerobic endurance training improves soccer performance. Medicine \& Science in Sports \& Exercise, 33(11), 1925-1931. doi: https://doi.org/10.1097/00005768-200111000-00019

Hill, A.P. (2013). Perfectionism and burnout in junior soccer players: A test of the $2 \times 2$ model of dispositional perfectionism. Journal of Sport \& Exercise Psychology, 35(1), 18-29. doi: https://doi.org/10.1123/jsep.35.1.18

Hopkins, W.G., Marshall, S.W., Batterham, A.M. \& Hanin, J. (2009). Progressive statistics for studies in sports medicine and exercise science. Medicine \& Science in Sports \& Exercise, 41(1), 3-12. doi: https://doi.org/10.1249/MSS.0b013e31818cb278

Hoshikawa, Y., Kanno, A., Ikoma, T., Muramatsu, M., lida, T., Uchiyama, A. \& Nakajima, Y. (2005). Off season and preseason changes in total and regional body composition in Japanese professional soccer league players. Presented at World congress on science and soccer. Retrieved from https://www.tib.eu/en/search/id/BLCP:CN055736453/Offseason-and-pre-season-changes-in-totaland?cHash=0a269ab4642cc8828a00b7f4790d2a7a

Impellizzeri, F.M., Marcora, S.M., Castagna, C., Reilly, T., Sassi, A., laia, F.M. \& Rampinini, E. (2006). Physiological and performance effects of generic versus specific aerobic training in soccer players. International Journal of Sports Medicine, 27(6), 483-492. doi: https://doi.org/10.1055/s-2005-865839

Jastrzębski, Z., Dargiewicz, R., Ignatiuk, W., Radzimiński, L., Rompa, P. \& Konieczna, A. (2011). Lactate threshold changes in soccer players during the preparation period. 
Baltic Journal of Health and Physical Activity, 3(2), 96-10. doi: https://doi.org/10.2478/v10131-011-0009-1

Jastrzębski, Z., Barnat, W., Konieczna, A., Rompa, P., \& Radzimiński, L. (2011). Physical capacity and soccer-related skills in young soccer players with in a one-year period. Baltic Journal of Health and Physical Activity, 3(4), 248-261. doi: https://doi.org/10.2478/v10131-011-0024-2

Kraemer, W.J., French, D.N., Paxton, N.J., Hakkinen, K., Volek, J.S., Sebastianelli, W.J. ... Knuttgen, H. (2004). Changes in exercise performance and hormonal concentrations over a big ten soccer season in starters and nonstarters. Journal of Strength Conditional Research, 18(1), 121-128. doi: https://doi.org/10.1519/15334287(2004)018<0121:ciepah>2.0.co;2

Malina, R.M., Peña Reyes, M.E., Eisenmann, J.C., Horta, L., Rodrigues, J. \& Miller, R. (2000). Height, mass and skeletal maturity of elite Portuguese soccer players aged 11-16 years. Journal of Sports Sciences, 18(9), 685-693. doi: https://doi.org/10.1080/02640410050120069

McMillan, K., Helgerud, J., Grant, S.J., Newell, J., Wilson, J., Macdonald, R. \& Hoff, J. (2005). Lactate threshold responses to a season of professional British youth soccer. British Journal of Sports Medicine, 39(7), 432-436. doi: https://doi.org/10.1136/bjsm.2004.012260

Mohr, M., Krustrup, P. \& Bangsbo, J. (2002). Physiological characteristics and exhaustive exercise performance of elite soccer players during a season. Medicine \& Science in Sports \& Exercise, 34(5). Retrieved from https://journals.lww.com/acsmmsse/Fulltext/2002/05001/PHYSIOLOGICAL CHARACTERISTICS AND EXHAUST IVE.132.aspx

Mohr, M., Krustrup, P. \& Bangsbo, J. (2003). Match performance of high-standard soccer players with special reference to development of fatigue. Journal of Sports Sciences, 21(7), 519-528. doi: https://doi.org/10.1080/0264041031000071182

Mohr, M. \& Krustrup, P. (2014). Yo-Yo intermittent recovery test performances within an entire soccer league during a full season. Journal of Sports Sciences, 32(4), 315-327. doi: https://doi.org/10.1080/02640414.2013.824598

Morris, R., Emmonds, S., Jones, B., Myers, T.D., Clarke, N.D., Lake, J., Ellis, M., Singleton, D., Roe, G. \& Till, K. (2018). Seasonal changes in physical qualities of elite youth soccer players according to maturity status: comparisons with aged matched controls, Science and Medicine in Soccer, 2(4), 272-280. doi: https://doi.org/10.1080/24733938.2018.1454599

Reilly, T. \& Williams, A. (2003). Science and Soccer ( $2^{\text {nd }}$ ed.). London: Routledge. 
Roe, M. \& Malone, S. (2016). Yo-Yo intermittent recovery test performance in subelite Gaelic soccer players from under thirteen to senior age groups. The Journal of Strength and Conditioning Research, 30(11), 3187-3193. doi: https://doi.org/10.1519/JSC.0000000000001417

Sagelv, E.H., Selnæs, I., Pedersen, S., Pettersen, S.A., Randers, M.B. \& Welde, B. (2019). Effects of linear versus changes of direction repeated sprints on intermittent high intensity running performance in high-level junior soccer players over an entire season: A randomized Trial. Sports, 7(8), 189. doi: https://doi.org/10.3390/sports7080189

Sæther, S.A. \& Aspvik, N.P. (2014). Seasonal variation in objectively assessed physical activity among young Norwegian talented soccer players: A description of daily physical activity level. Journal of Sports Science and Medicine, 13(4), 964-968. Retrieved from https://pubmed.ncbi.nlm.nih.gov/25435792/

Silva, J.F., Nakamura, F.Y., Carminatti, L.J., Dittrich, N., Cetolin, T. \& Guglielmo, L.G.A. (2015). The effect of two generic aerobic interval training methods on laboratory and field test performance in soccer players. Journal of Strength and Conditioning Research, 29(6), 1666-1672. doi: https://doi.org/10.1519/JSC.0000000000000776

Sylejmani, B., Maliqi, A., Gontarev, S., Haziri, S., Morina, B., Durmishaj, E., \& Bajrami, A. (2019). Anthropometric characteristics and physical performance of young elite Kosovo soccer players. International Journal of Morphology, 37(4), 1429-1436. Retrieved from http://www.intjmorphol.com/wp-content/uploads/2019/09/art 38 374.pdf

Teixeira, A.S., Da Silva, J.F., Carminatti, L.J., Dittrich, N., Castagna, C., \& Guglielmo, L.G.A. (2014). Reliability and validity of the Carminatti's test for aerobic fitness in youth soccer players. The Journal of Strength and Conditioning Research, 28(11), 3264-3273. doi: https://doi.org/10.1519/JSC.0000000000000534

Teplan, J., Maly, T., Zahalka, F., Hrasky, P., Mala, L. \& Heller, J. (2012). The level and differences of aerobic capacity in three different young soccer teams in the U17 category. Sport Science, 5(1), 43-48. Retrieved from https://www.sposci.com/PDFS/BR0501/SVEE/04\%20CL\%2008\%20JT.pdf

Thomas, A., Dawson, B., \& Goodman, C. (2006). The yo-yo test: reliability and association with a 20-m shuttle run and VO(2max). International Journal of Sports Physiology and Perform, 1(2),137-49. doi: https://doi.org/10.1123/ijspp.1.2.137

Vanttinen, T., Blomqvist, M., Nyman, K., \& Hakkinen, K. (2011). Changes in body composition, hormonal status and physical fitness in 11,13 and 15 year old Finnish regional youth soccer players during a two year follow-up. The Journal of Strength and Conditioning Research, 25(12), 3342-3351. doi: https://doi.org/10.1519/JSC.0b013e318236d0c2 